\title{
The Influences of Business and Decision Makers' Characteristics on Disaster Preparedness-A Study on the 1989 Loma Prieta Earthquake
}

\author{
Ziqiang Han* and Joanne Nigg \\ Disaster Research Center, University of Delaware, Newark, DE 19716, USA
}

\begin{abstract}
Disaster preparedness is very important for business continuity, but the determinants of disaster preparedness in business organizations have not been explored much in existing research. Therefore, in this article we undertake to analyze the influences of organizational and decision makers' characteristics on business disaster preparedness. In 1997, eight years after the Loma Prieta earthquake, the Disaster Research Center at University of Delaware conducted a large-scale mail questionnaire survey in Santa Cruz County, California, which was hard-hit by the 1989 earthquake. A total of 933 completed surveys from business organizations were obtained. Our analysis is based on this historical dataset. The results revealed that larger companies are more likely to engage in disaster preparedness activities, which is consistent with previous studies. Companies in finance, insurance, and real estate sectors tend to prepare more for disasters compared with wholesale and retail trade firms. Disaster experience has a significant and positive impact on business disaster preparedness, and the degree of lifeline loss can be a reasonable indicator of the disaster experiences of business organizations. One interesting finding is that the better a company's financial condition is, the less it will engage in preparing for disasters. Finally, the risk perception of business owners or decision makers has a statistically significant and consistent positive effect on business disaster preparedness activities.
\end{abstract}

Keywords business, disaster experience, disaster preparedness, risk perception

\section{Introduction}

Businesses are essential for community functioning because they provide products/services, employment opportunities, and taxes (Cochrane 1992). Pre-disaster preparation is very important for business continuity and post-disaster recovery (Corey and Deitch 2011). Yet research about business organizations' mitigation, preparedness, response, and recovery from disasters is rare, although there is a long tradition of

\footnotetext{
* Corresponding author. E-mail: ziqiang@udel.edu
}

organizational research in public sector institutes (Dahlhamer and Reshaur 1996).

Thus, the Disaster Research Center (DRC) at University of Delaware initiated a series of systematic studies with large and representative samples exploring the disaster-related experiences of business organizations in communities around the U.S. between 1993 and 1998. These studies included one project in the nondisaster context in Memphis/Shelby County, and four studies in communities that had experienced four of the most severe and costly disasters in U.S. history: the 1989 Loma Prieta earthquake; Hurricane Andrew in 1992; the 1993 Midwest floods; and the 1994 Northridge earthquake. Tierney, Nigg and other former researchers at DRC had developed a number of research papers (Dahlhamer and D’Souza 1997; Dahlhamer and Reshaur 1996; Nigg 1995; Tierney and Nigg 1995; Webb, Tierney, and Dahlhamer 2000; Webb, Tierney, and Dahlhamer 2002; Wasileski, Rodriguez, and Diaz 2011) based on the dataset from these projects. To date the disaster preparedness of business organizations has not been fully explored. In recent years, economic losses from natural disasters have increased (UNISDR 2011; Cutter and Emrich 2005), but large-scale, disaster-related studies about business organizations have remained infrequent. Therefore, a reanalysis of the DRC historical dataset, together with an exploration of how the organizational characteristics of businesses and individual characteristics of decision makers influence disaster preparedness, should provide the insight needed to improve disaster preparedness in business settings.

\section{Determinants of Business Disaster Preparedness}

\subsection{Organizational Factors}

Various characteristics of business organizations have an important influence on business disaster preparedness. These include primarily the following features based on case studies across the United States and in other countries. 


\section{Firm size}

Prior research suggests that the most consistent firm characteristic related to disaster preparedness is firm size, usually measured by the number of full-time employees. Quarantelli and his colleagues (Quarantelli et al. 1979) were among the first to address disaster preparedness within the commercial sectors. In one of their early studies, which focused on chemical companies in 18 communities across the United States, they found that larger chemical companies had engaged in more planning than their smaller counterparts. It is not difficult to understand that small companies may not have enough resources to devote to disaster preparedness. Drabek's studies of tourist-oriented firms in the 1990s also showed that the number of employees in a company had a strong correlation with the extent of their disaster evacuation planning (Drabek 1991, 1994a, 1994b, 1995). In Dahlhamer and D'Souza's (1997) studies using the data from Memphis/ Shelby County, Tennessee and Des Moines/Polk County, Iowa, the larger businesses were more likely to engage in preparedness activities than their small counterparts-size was the strongest predictor of preparedness among business organizations in both communities. More recent studies at the organizational level also found that organizational size is a strong positive determinant of disaster mitigation and preparedness in organizations (Sadiq 2010, 2011). These studies revealed consistently that the size of a company is a strong predictor of its disaster preparedness.

\section{Firm age}

How long a firm has been in business also indicates the experiences and capacity of an organization's disaster preparedness. But the influence of firm age on disaster preparedness is not consistent in previous research. Quarantelli's research in the 1970s showed that newer chemical companies were more likely to engage in both intensive and extensive disaster planning than older chemical firms (Quarantelli et al. 1979). Using bivariate analyses, other researchers have found that firm age had a significant, positive influence on preparedness among 80 companies (Banerjee and Gillespie 1994). Also Drabek's study (1994a) of 180 firms, age of the companies did not significantly influence their evacuation planning.

\section{Location patterns}

Ownership and location patterns may be additional influencing factors in disaster preparedness. In the studies of both Quarantelli and colleagues and Drabek, those companies with multiple sites or the firms that were part of larger national chains were more likely to engage in disaster preparedness (Quarantelli et al. 1979; Drabek 1991, 1994a, 1994b, 1995). Qurantelli and his colleagues (1979) believed that this was largely due to corporate mandates and policy directives that instructed national companies to develop chemical disaster preparedness programs.

\section{Property ownership}

Ownership of property of businesses can be another important factor that affects the business decision makers' preparation for disasters. Compared with renters or leasers, property owners may feel that their assets are at higher risk, and thus may be more concerned about disaster reduction. In Dahlhamer and D'Souza's (1997) studies in Memphis and Des Moines, they discovered that the firms that owned their property were more likely to engage in preparedness activities compared to the renters or leasers.

\section{Financial condition}

Even when business organizations have the willingness to prepare for disasters and emergencies, if they don't have enough resources, especially financial resources, they still cannot implement the desired disaster preparedness activities. Quarantelli et al.'s research (1979) found that wealthier chemical companies were more likely to engage in planning than smaller local firms that could not afford to do so. Alesch and his coworkers' findings also pointed out that small firms tended to be particularly vulnerable to disaster impacts and losses since they often had fewer cash reserves and frequently could not afford to engage in various preparedness activities (Alesch et al. 1993).

\section{Sector differences}

Generally speaking, most safety measures that businesses undertake are done voluntarily since there are few outright mandates governing business mitigation and preparedness (Tierney 2007). Firms in different business sectors may have different government regulations, thus they may be required to engage in different types of disaster preparedness. In Dahlhamer and D'Souza's research (1997), the finance, insurance, and real estate sectors were significantly more likely to engage in disaster preparedness activities than firms in other sectors (agriculture, forestry, fishing, mining, transportation, communications, and utilities) in the Memphis area. Also, firms that had staff with preparedness activities included as part of their jobs and executives often had higher levels of risk awareness, and were more likely to engage in disaster preparedness activities (Mileti et al. 1993).

\section{Previous experiences}

One could assume that previous disaster experiences may have an effect on disaster preparedness activities. The results of Dahlhamer and D'Souza's (1997) research in both Memphis and Des Moines confirmed that business organizations with previous disaster experience were more likely to prepare for disasters. Drabek's (1994a, 1994b) studies similarly concluded that tourist-oriented firms with no or little disaster experience tended to do less disaster preparedness. Another study also indicated that industrial facilities that had suffered earthquake damages increased their preparedness activities significantly after the earthquake (Cruz and Steinberg 2005). 
The influence of past disaster experiences on people's decisions appears particularly evident in insurance markets for catastrophic disasters. For example, the number of individuals in California who purchased insurance increased significantly after the 1989 Loma Prieta earthquake (Kunreuther 1996). A similar relationship was also observed by an empirical study about flood insurance purchasing and flood experience (Browne and Hoyt 2000). However, it should be noted that how disaster experience is measured is very important. Some studies have shown that only people who actually experienced severe losses due to a disaster would take the consequences of a disaster more seriously (Siegrist and Gutscher 2008).

\subsection{Individual Factors}

Past studies show that the most significant contributor to disaster preparedness is people's risk perceptions. Lindell and Perry (2000) reviewed household adjustment to earthquake hazard using data from 23 studies. They found that in most of the studies there were significant correlations between risk perception and seismic adjustment, though the results were not consistent. Some newer studies also found that people's risk attitudes and risk perceptions are the main drivers of their decision-making behavior in times of crises and disasters (Pennings and Grossman 2008). Similar results were reported by other empirical studies - correlation and regression analyses indicated that disaster preparedness was positively associated with flood risk perception (Miceli, Sotgiu, and Settanni 2008). In a survey of 227 organizations in Memphis,
Tennessee, the results also revealed that concern over disaster impact was a strong positive determinant of mitigation and preparedness in organizations (Sadiq 2010).

Household studies have indicated that some demographic characteristics, including gender, age, ethnicity, and marital status, may be correlated with disaster preparedness activities (Tierney 2001). For example, ethnic minorities may show a lower probability to prepare for disasters, while white males may be more likely to engage in these activities, although their levels of preparedness still tend to be low compared to what they could be doing (Lindell and Prater 2000). Another study also indicated that the female, younger, and non-Anglo populations had more concern and a greater likelihood of preparation (Dooley et al. 1992).

As the most important and influential stakeholders of business organizations, the characteristics of business owners or decision makers affect the organizations' disaster preparedness activities. Risk perception, gender, and ethnicity of firm owners or decision makers are therefore included in this analysis.

\subsection{Framework of Analysis}

A conceptual and analytical framework (Figure 1) is constructed based on the disaster preparedness literature reviewed above. The influencing factors of business disaster preparedness are divided into two blocks: the features of business organizations, and the firm owners or decision makers' characteristics.

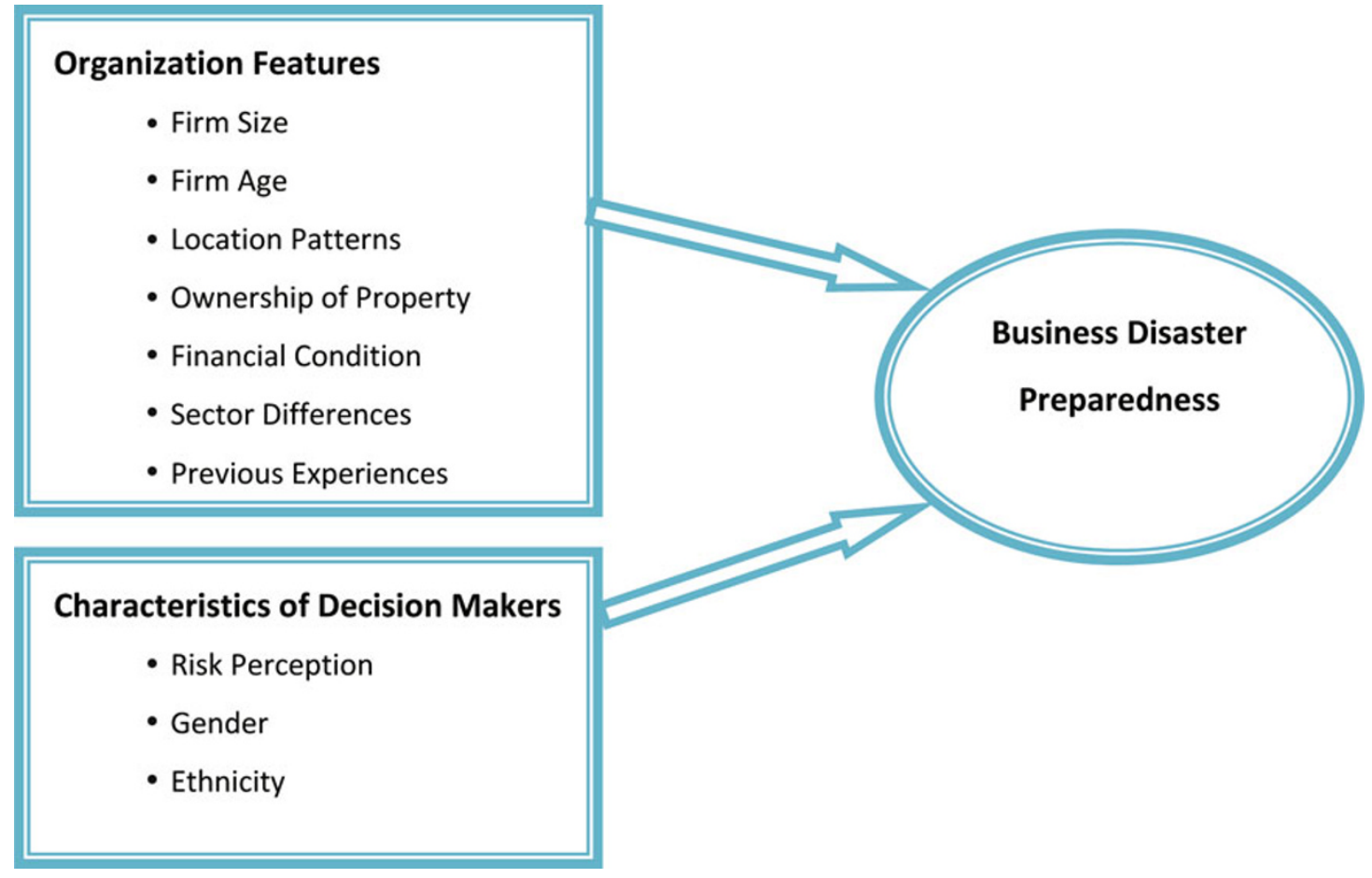

Figure 1. Analytical framework: factors influencing business disaster preparedness 
Firm size, which is always measured by the number of full-time employees, firm age, location patterns, ownership of property, financial condition at the time of the survey, and sectors that the firms belonged to are the main contents of the business attributes block. As all the business organizations in this study had experienced the 1989 Loma Prieta earthquake, the damage degree from the earthquake can be used as the indicator of previous disaster experience.

The block of owners or decision makers' characteristics mainly contains risk perception of prospective earthquakes and gender and ethnicity of the business owners/decision makers. Combined with the features of business organizations, the influence of these factors on the number of business disaster preparedness activities measured in 1997 are examined in this article.

\section{Methodology}

In 1997, eight years after the Loma Prieta earthquake, the Disaster Research Center at University of Delaware conducted a systematic, large-scale mail questionnaire survey in Santa Cruz County, California, which was hard-hit by the 1989 earthquake.

\subsection{Data Collection Method}

Business information data from the Dun \& Bradstreet Information Services was used to establish the sampling frame for this study area, and 3075 businesses in Santa Cruz County were included. The data for this survey was collected through a modified version of Dillman's "total design method" (Dillman 1978). In June 1997, surveys were mailed to the owners of the 3075 businesses that met the study criteria. Some firms were later removed due to reasons such as: the business was not actually in existence at the time of the earthquake; the business was not operating at the time of the disaster; the business closed prior to the data collection; the organization that received the survey was not a private, for-profit firm; or the firm could not be located after exhaustive searches. Finally, 933 completed surveys were returned and coded for analysis, yielding a response rate of 33.6 percent.

\subsection{Key Variables and Measurements}

Business disaster preparedness is measured by an index derived from a series of preparedness activities. The researchers in the Disaster Research Center constructed a checklist of 17 business disaster preparedness activities according to literature review and their rich research experience carrying out the five cross-sectional business and disaster studies mentioned in the introductory section. These 17 items (Table 1) covered a wide range of activities from material preparation, insurance purchasing to knowledge enrichment:

\section{Table 1. Business disaster preparedness activities}

(1) Attended meetings or received written information on earthquake preparedness;

(2) Talked with those working in your business about what to do in the event of an earthquake;

(3) Purchased earthquake insurance to cover damage to your business;

(4) Purchased business interruption insurance;

(5) Stored extra fuel or batteries;

(6) Learned first aid;

(7) Obtained a first aid kit or extra medical supplies;

(8) Developed a business emergency plan, covering what to do if an earthquake strikes;

(9) Developed a business disaster recovery plan;

(10) Conducted earthquake drills or exercises for your employees;

(11) Been involved in any earthquake preparedness or response training programs for your employees;

(12) Made arrangements to move the business to another location in case of an earthquake;

(13) Obtained an emergency generator for use if electrical power fails;

(14) Purchased a cellular phone for use if telephone fails;

(15) Taken action to brace shelves or heavy objects that might move during an earthquake;

(16) Storedw ater;

(17) Had an engineer or other qualified person assess the structural safety of your building for earthquake.

If a respondent reported an activity, one point is added to the business disaster preparedness index. Therefore, business disaster preparedness is measured by a continuous variable from zero to 17 , which indicates the total number of activities they conducted for potential earthquakes. Meanwhile, an index that measures the business organizations' preparedness activities before the 1989 earthquake using the same questions and scales was generated as a control variable in this analysis.

Risk perception is an important influencing factor in our analysis. There are two fundamental ways in which human beings comprehend risk: risk as analysis and risk as feeling (Slovic et al. 2004). The risk behavior literature identified that the content of the risk and the likelihood of actual exposure to that content are the two dimensions that play an important role in how decision makers respond to risk, and these two dimensions are directly related to risk attitude and risk perception (Pratt 1964; Arrow 1971; MacCrimmon, Wehrung, and Stanbury 1988; Slovic 1987). Risk perceptions have been measured more specifically in terms of the characteristics of a hazard event such as probability and severity (Kunreuther et al. 1978; Mulilis and Lippa 1990).

In the context of this article, the main threat to all the firms is earthquake; therefore, the decision makers' risk perception can be generated by the likelihood of exposure to future earthquakes. Four questions were asked to estimate the decision makers' risk perception of future earthquakes, of which the first three concern their estimated probability of an earthquake, that is, how likely they think that a damaging earthquake will hit their area in the next 30,10, and one year; the fourth question concerns their perception of the severity, that is, how much damage to the business is expected if a 
damaging earthquake does strike. All four indicators are measured in a $0-3$ scale, with zero representing the perceived lowest likelihood of occurrence/damage, and three representing the highest likelihood/damage. Finally, the product of the probability and severity degree was used to measure the owners or decision makers' risk perception.

Disaster experience is another important yet complicated influencing factor. In this study, all the respondents had experienced the 1989 Loma Prieta earthquake. It was possible that firms that experienced different levels of damage may have varied levels of disaster preparedness after the earthquake. High levels of damage influence awareness of the need for disaster preparedness (Mileti, Drabek, and Haas 1975). Studies revealed that the loss of lifeline services can be a good indicator of disaster damage and experience at the organizational level, as the lifeline services (electricity, phone, water, sewer, gas), especially the electricity and phone services, are critical for business continuity (Nigg 1995). The sum of the five lifeline services disruption status is used as a disaster loss indicator in this article. Except for lifeline service loss, two other dummy variables that indicate whether the businesses were closed due to the earthquake or damaged by the earthquake were also used as possible indicators of business disaster experience.

Firm size and age are measured by the actual numbers. Location patterns are divided into franchise/chain/multiplesites type and single-location type and are represented by a dummy variable. So is the property ownership variable, which is divided into leased and owned categories. Business sectors include wholesale/retail, manufacturing/construction, services, finance/insurance/real estate, and others. Financial condition is represented by in trouble, not bad but not good either, and good/excellent types. Among the individual characteristics, both gender and ethnicity are represented by dummy variables, with the latter divided into white and non-white owners.

\section{Results}

\subsection{Descriptive Analysis}

This survey was conducted in 1997, eight years after the Loma Prieta earthquake. All the respondents were business organizations in the Santa Cruz area that had experienced the Loma Prieta earthquake in 1989. On average, each company adopted 5.59 disaster preparedness activities in 1997 when the survey was conducted, compared with 3.5 preparedness activities before the 1989 earthquake (Table 2) - the total number of disaster preparedness activities almost doubled.

Table 2 also shows the descriptive statistics for the organizational features of businesses. Most of the respondents were small businesses and had operated in the Santa Cruz area for quite a long time. The average number of full-time employees in these companies was 11.63 and the mean value of the firm age was 28.07 years. Since most of these firms were not big companies, more than 80 percent of them were individual firms located in a single location and about 60 percent did not own their business property. Most of these business organizations were in good financial condition in 1997. About 71.3 percent reported that the company was in a good or excellent financial condition while only 6.17 percent of the respondents were in financial trouble or marginal situation at the time of the survey. Firms in finance, insurance, or real estate accounted for about 10 percent of the total number, one third of the organizations were wholesale or retail business, and another third performed service activities.

The results of disaster experience related variables are also shown in Table 2. About half of the firms' buildings had been damaged and more than three quarters of these businesses had been closed due to the Loma Prieta earthquake. The mean value of the lifeline loss index was 2.4 , which was about half of the maximum possible loss value (5). The most impacted lifeline services in the earthquake were electrical service and phone service, which were the most important lifeline services for business continuity. More than 90 percent of the respondents reported an electricity loss, and about 75 percent experienced phone service interruptions. About 40 percent of the businesses suffered from water service loss, 25 percent experienced interruptions in natural gas supply, and less than 10 percent of the firms reported a loss of sewer service.

Table 3 shows that most of the business organizations (94.32 percent) in this survey were owned by white people, and more than 80 percent were owned by males. As the questionnaire mainly targeted business owners or decision makers, the risk perception obtained from respondents largely reflects the attitudes of business owners or decision makers. The respondents believed that the probability of a potentially damaging earthquake happening in the Santa Cruz area was very high. Asked when a damaging earthquake might recur, nearly 90 percent of respondents believed that a damaging earthquake could occur in the next thirty years, about 65 percent favored a quake in the next ten years, and nearly a quarter expected another significant event in the next year. If a damaging earthquake did strike the area, only 4.64 percent of the respondents thought there would be no damage, 57.19 percent believed that there would be minor damage, 32.37 percent anticipated moderate damage, and 5.8 percent expected severe damage. Meaningful numbers from 0 to 3 were labeled separately to determine the degree of probability and severity. The risk perception of business owners and decision makers variable, which is the product of the total perceived probability in the three situations and the severity of earthquake, has an average value of 7.26 (the highest possible value is 27).

\subsection{Regression Analysis}

In order to explore the effect of each influencing factor on the business disaster preparedness behaviors, the four models shown in Table 4 were constructed. The dependent variable of these models is the business disaster preparedness index at 
Table 2. Survey results: Disaster preparedness and organizational attributes

\begin{tabular}{|c|c|c|c|c|c|}
\hline Variable & Content & Observation & Mean & & SD \\
\hline Post-disaster preparedness & Continuous, $\min 0 \max 17$ & 896 & 5.59 & & 3.98 \\
\hline Pre-disaster preparedness & Continuous, $\min 0 \max 17$ & 896 & 3.50 & & 3.44 \\
\hline Age of firm & Years & 911 & 28.07 & & 19.09 \\
\hline Fulltime employees & Continuous & 909 & 11.63 & & 32.30 \\
\hline \multirow[t]{2}{*}{ Lifeline loss indicator } & Continuous variable $(0-5)$ & 688 & 2.40 & & 1.24 \\
\hline & & Frequency & \multicolumn{3}{|c|}{ Percent } \\
\hline \multirow[t]{2}{*}{ Loss of electrical service } & $0=\mathrm{No}$ & 82 & \multicolumn{3}{|c|}{8.92} \\
\hline & $1=$ Yes & 837 & \multicolumn{3}{|c|}{91.08} \\
\hline \multirow[t]{2}{*}{ Loss of phone service } & $0=\mathrm{No}$ & 229 & \multicolumn{3}{|c|}{24.97} \\
\hline & $1=$ Yes & 688 & \multicolumn{3}{|c|}{75.03} \\
\hline \multirow[t]{2}{*}{ Loss of water service } & $0=\mathrm{No}$ & 553 & \multicolumn{3}{|c|}{60.57} \\
\hline & $1=$ Yes & 360 & \multicolumn{3}{|c|}{39.43} \\
\hline \multirow[t]{2}{*}{ Loss of sewer service } & $0=\mathrm{No}$ & 819 & \multicolumn{3}{|c|}{90.30} \\
\hline & $1=$ Yes & 88 & \multicolumn{3}{|c|}{9.70} \\
\hline \multirow[t]{2}{*}{ Loss of gas service } & $0=\mathrm{No}$ & 518 & \multicolumn{3}{|c|}{73.58} \\
\hline & $1=$ Yes & 186 & \multicolumn{3}{|c|}{26.42} \\
\hline \multirow[t]{2}{*}{ Damaged due to the earthquake } & $0=$ No Damage & 445 & \multicolumn{3}{|c|}{47.80} \\
\hline & $1=$ Damage & 486 & \multicolumn{3}{|c|}{52.20} \\
\hline \multirow[t]{2}{*}{ Closed due to the earthquake } & $0=\mathrm{No}$ & 223 & \multicolumn{3}{|c|}{24.13} \\
\hline & $1=$ Yes & 701 & \multicolumn{3}{|c|}{75.87} \\
\hline \multirow[t]{2}{*}{ Location patterns } & $0=$ Franchise $/$ Chain/Multiple sites & 178 & \multicolumn{3}{|c|}{19.56} \\
\hline & $1=$ Single location & 732 & \multicolumn{3}{|c|}{80.44} \\
\hline \multirow[t]{2}{*}{ Ownership of property } & $0=$ Property Leased & 554 & \multicolumn{3}{|c|}{61.49} \\
\hline & $1=$ Property Owned by Business & 347 & \multicolumn{3}{|c|}{38.51} \\
\hline \multirow[t]{5}{*}{ Business sectors } & $1=$ Wholesale/Retail & 289 & & 30.98 & \\
\hline & $2=$ Manufacturing/Construction & 165 & & 17.68 & \\
\hline & $3=$ Services & 325 & & 34.83 & \\
\hline & 4=Finance/Insurance/Real Estate & 93 & & 9.97 & \\
\hline & $5=$ Others & 61 & & 6.54 & \\
\hline Financial condition & $1=$ In Trouble & 55 & & 6.17 & \\
\hline & $2=$ Not Bad, Not Good & 201 & & 22.53 & \\
\hline & $3=$ In Good/Excellent & 636 & & 71.30 & \\
\hline
\end{tabular}

Source: The authors.

the survey time, and a similar index of pre-disaster activities before the 1989 earthquake was used as the control variable. The independent variables include the business attributes and the owner/decision makers' characteristics presented in the methodology section.

As the dependent variable is a continuous variable, the classic linear regression model (CLRM) using the ordinary least squares (OLS) method was adopted for the analysis. Because the dependent variable also has a minimum and maximum value ( 0 to 17$)$, a Tobit model might estimate the effect of explanatory variables more precisely (Gujarati 2011). Therefore, the first three models presented are classic linear regression models, and the last one used is the Tobit model. The first model only includes the owners/decision makers' characteristics and the control variable. The second one contains all the business organizational factors. Both organizational and personal characteristics are included in the third model, but some statistically nonsignificant variables (as indicated by the first two models), including gender, ethnicity, location patterns, and property ownership are excluded from the model. Also, the alternative measurements of disaster experience (the two dummy variables, closure, and damage) are excluded because they are not only statistically insignificant, but also caused a multicollinearity problem if they were included in the model with the lifeline loss variable. The result of the Tobit model is shown in the last column of Table 4. In addition to the coefficients of the variables, the number of observations $(N)$ obtained by the model and the adjusted $R^{2}$, which is generally used to measure the explanation power of the model, are also reported.

The risk perception of business owners has a statistically significant positive effect on their business disaster preparedness activities. All the results in the three models show a similar pattern. With control of the organizational factors, the effect of risk perception on preparedness activities is a little stronger. But the other demographic characteristics (gender and ethnicity) of business owners and decision makers have no significant influence on business preparedness activities, although the results indicate that woman and nonwhite owners tend to prepare more for disasters.

The most influential organizational factor on business preparedness activities is the firm's size, which is measured 
Table 3. Survey results: Business owners or decision makers' characteristics

\begin{tabular}{|c|c|c|c|c|c|}
\hline Variable & Content & Observation & Mean & & SD \\
\hline \multirow[t]{2}{*}{ Risk perception } & \multirow[t]{2}{*}{ Continuous variable $(0-27)$} & 834 & 7.26 & & 4.84 \\
\hline & & Frequency & & Percent & \\
\hline \multirow[t]{4}{*}{ Earthquake in next 30 years } & $0=$ Not Likely At All & 18 & & 1.96 & \\
\hline & 1=Not Very Likely & 90 & & 9.81 & \\
\hline & $2=$ Likely & 417 & & 45.47 & \\
\hline & $3=$ Very Likely & 392 & & 42.75 & \\
\hline \multirow[t]{4}{*}{ Earthquake in next 10 years } & $0=$ Not Likely At All & 38 & & 4.19 & \\
\hline & $1=$ Not Very Likely & 266 & & 29.33 & \\
\hline & $2=$ Likely & 469 & & 51.71 & \\
\hline & $3=$ Very Likely & 134 & & 14.77 & \\
\hline \multirow[t]{4}{*}{ Earthquake in next year } & $0=$ Not Likely At All & 203 & & 22.78 & \\
\hline & 1=Not Very Likely & 466 & & 52.3 & \\
\hline & $2=$ Likely & 203 & & 22.78 & \\
\hline & $3=$ Very Likely & 19 & & 2.13 & \\
\hline \multirow{4}{*}{$\begin{array}{r}\text { Expected severity to business if } \\
\text { earthquake happened }\end{array}$} & $0=$ No Damage & 40 & & 4.64 & \\
\hline & 1=Minor Damage & 493 & & 57.19 & \\
\hline & $2=$ Moderate Damage & 279 & & 32.37 & \\
\hline & $3=$ Severe Damage & 50 & & 5.8 & \\
\hline \multirow[t]{2}{*}{ Woman-owned business } & 1=Woman-owned & 172 & & 18.74 & \\
\hline & $0=$ Others & 746 & & 81.26 & \\
\hline \multirow[t]{2}{*}{ Owner is non-white } & $1=$ Non-white owner & 52 & & 5.68 & \\
\hline & $0=$ Others & 863 & & 94.32 & \\
\hline
\end{tabular}

Source: The authors.

Table 4. Determinants of business preparedness activities

\begin{tabular}{|c|c|c|c|c|}
\hline Variable & $\begin{array}{l}\text { OLS_ } \\
\text { Owner }\end{array}$ & $\underset{\text { Organization }}{\text { OLS__ }}$ & OLS_All & Tobit \\
\hline Preparedness in 1989 & $.732 * * *$ & $.657 * * *$ & $.66^{* * *}$ & $.695 * * *$ \\
\hline Woman-owned & .134 & & & \\
\hline Non-white-owned & .719 & & & \\
\hline Risk perception & $.0844 * * *$ & & $.105^{* * *}$ & $.112 * * *$ \\
\hline Firm age & & -0.0075 & -.0117 & $-.015^{*}$ \\
\hline Firm size & & $.436^{* * *}$ & $.375^{* *}$ & $.395 * *$ \\
\hline Single location & & .0442 & & \\
\hline Owned property & & .118 & & \\
\hline \multicolumn{5}{|l|}{ Sector } \\
\hline $\begin{array}{l}\text { Manufacturing/ } \\
\text { Construction }\end{array}$ & & 0.323 & -0.115 & -.238 \\
\hline Services & & 0.557 & 0.368 & .351 \\
\hline $\begin{array}{l}\text { Finance/Insurance/ } \\
\text { Real estate }\end{array}$ & & $1.81 * * *$ & $1.37 * *$ & $1.42 * *$ \\
\hline Others & & $1.31 *$ & 1.09 & 1.20 \\
\hline Financial condition & & $-.759 * *$ & $-.586^{*}$ & $-.660 *$ \\
\hline Lifeline loss & & $.427 * * *$ & $.471 * * *$ & $.50 * * *$ \\
\hline Damage & & 0.326 & & \\
\hline Closure & & 0.364 & & \\
\hline$N$ & 797 & 513 & 493 & 452 \\
\hline $\operatorname{Adj} R^{2}$ & 0.4199 & 0.4031 & 0.4250 & $\begin{array}{c}0.1006 \\
\left.\text { (Peseudo } R^{2}\right)\end{array}$ \\
\hline
\end{tabular}

Note: ${ }^{*} p<.05 ;{ }^{* \star} p<.01 ;{ }^{* * *} p<.001$

by the number of fulltime employees. The results of all models revealed that the larger a company, the more preparedness activities it would adopt, and this positive effect is statistically significant at the 0.001 level. Compared with wholesale or retail trade companies, firms in the finance, insurance, and real estate sectors were more likely to undertake disaster preparedness activities. A similar result also shows in other sectors such as agriculture, forestry, fishing, mining, and communications. Both of these effects are statistically significant.

The results of this analysis indicate that old firms tended to prepare less for disasters, but this negative influence was very small and not significant. In the Tobit model, however, which censored the zero value of the dependent variable, this coefficient became significant at the 0.05 level. Compared with multiple-location or franchise firms, single-location firms were more likely to prepare for disasters. Also if a business owned its property, the company tended to implement more disaster preparedness measures than did renters and leasers. The effects of business location patterns and property ownership are not statistically significant.

It is not difficult to understand that the business organizations that prepared more for disasters before an earthquake would undertake more preparedness activities after. Actually, the control variable - preearthquake preparedness activities, had the strongest effect on the disaster preparedness measures adopted eight years later. As we have illustrated in the previous section, three indicators were used to measure disaster experience in this analysis. Both of the two dummy variables, "closed due to the earthquake" and "damaged due to the earthquake," had a positive but non-significant effect on business disaster preparedness. In contrast, the lifeline loss variable has a statistically significant positive effect on business preparedness activities. As these three variables have a multicollinearity problem, we excluded the "damage" and 
"closure" variables in the last two models, but kept the lifeline loss variable as the indicator of business disaster experience.

An interesting result revealed in this analysis is that the financial condition of firms at the time of the survey has a significant negative effect on the adoption of the disaster preparedness activities in business organizations. It seems that the firms in better financial condition would do less to prepare for disasters than their counterparts.

\section{Discussions and Conclusion}

Studies in different times have reached a similar conclusion that larger firms are more likely to engage in preparing for disasters. Having more fulltime employee means that the companies are more "formal," and have more capacity to prepare for disasters (Quarantelli et al. 1979). However, the capacity to prepare for disasters should be carefully defined and examined. For example, the business organizations with more employees tend to adopt more disaster preparedness activities, but the companies in good financial conditions prefer to prepare less when compared with their counterparts. A more detailed examination of these companies needs to be done in order to explore the relationship between capacity and preparedness. Richer companies should have more money to prepare for disasters (Quarantelli et al. 1979), but the "whitemale effect," the overconfidence and lower risk awareness in this population, is commonly observed in risk related studies (Finucane et al. 2000). Therefore, further investigation will provide an improved understanding of business disaster mitigation and preparedness activities.

Business organizations in different sectors vary in disaster preparedness. The firms in the finance, insurance, and real estate sectors generally prepared more for disasters. Some studies that compared these firms with agriculture, forestry, finishing, and mining companies reached a conclusion (Dahlhamer and D'Souza 1997) similar to what we have found in this article. It would be meaningful to explore whether this difference comes from varied policy regulations in different sectors or from voluntary adaptations due to different business cultures. The better we understand the drivers of this difference, the better policy recommendations we can propose for disaster and emergency governance in the future.

Findings about the impact of a firm's age on its disaster preparedness remain inconsistent. In this analysis, the older companies prepare less for disasters, and this effect is only significant in the Tobit model, which excluded the censored data. Some previous studies showed that younger firms are more likely to engage in disaster preparedness activities (Quarantelli et al. 1979) while others had an opposite conclusion (Banerjee and Gillespie 1994). But it should be noted that the results are not significant in most of these studies.

Past disaster experience will not only influence people's risk perception of hazards (Weinstein 1989), but also affect people's protective behavior positively (Jackson 1981). But other research showed that experiencing a disaster does not necessarily lead to dramatic improvements in preparedness, at least not in the short term (Webb, Tierney, and Dahlhamer 2000). It is very likely that the varied measurements of disaster experiences have caused such inconsistency. For example, should we use direct economic losses due to a disaster or should we use closure time as the indicator of disaster experience? Is a dummy variable or a continuous variable more useful? The results from our analysis indicate that the loss of lifeline services can be a good indicator of a business organization's disaster experience, since the key lifeline services such as power supply and telephone service are very important for business continuity (Nigg 1995).

In our study, both the effects of business location patterns and the ownership of property on disaster preparedness are statistically insignificant, which is consistent with other studies. Results on these relationships also vary in different studies. Qurantelli and his colleagues (1979) and Drabek (1994a) mentioned that companies with multiple sites or firms that were part of larger national chains were more likely to engage in disaster preparedness activities, but similar effect did not show in Dahlhamer's studies with Reshaur (1996) and D'Sousa (1997). But in Dahlhamer's analysis using the business survey data in Memphis and Des Moines (Dahlhamer and D'Sousa 1997), the firms that owned their properties were more likely to engage in preparedness activities compared to renters or leasers.

For individuals, many empirical studies have confirmed that their risk perception has a positive effect on the adoption of hazard adjustments (Peacock 2003; Ozdemir and Yilmaz 2011).Our analysis supports the conclusion that the risk perception of business owners and decision makers will affect business disaster preparedness strongly and positively. Other studies also found that the concern over disaster impact is a strong positive determinant of mitigation and preparedness in organizations (Sadiq 2010). But the effect of the demographic characteristics of business owners or decision makers is unclear.

In conclusion, the size of organizations and the organizations' lifeline losses in previous disasters are the most consistent and significant drivers of business disaster preparedness at the organizational level. The owners and decision makers' perception of the risk of future disasters is the strongest and most significant predictor of business disaster preparedness at the personal level. Business organizations in finance, insurance, and real estate tend to prepare more for disasters than firms in other sectors. The effects of a firm's age, location pattern, and property ownership are not clear. These findings are consistent with most previous studies. But the negative effect of a firm's financial condition on disaster preparedness needs more careful investigation in future studies.

\section{Acknowledgment}

Ziqiang Han's Ph.D. studies at the Disaster Research Center, University of Delaware is supported by the China Scholarship Council. 


\section{References}

Alesch, D. J., C. Taylor, A. S. Ghanty, and R. A. Nagy. 1993. Earthquake Risk Reduction and Small Business. In National Earthquake Conference Monograph 5: Socioeconomic Impacts, edited by Committee on Socioeconomic Impacts, 133-60. Memphis, TN: Central United States Earthquake Consortium.

Arrow, K. J. 1971. Essays in the Theory of Risk-Bearing. Amsterdam: North-Holland Pub. Co.

Banerjee, M. M., and D. F. Gillespie. 1994. Strategy and Organizational Disaster Preparedness. Disasters 18 (4): 344-54.

Browne, M. J., and R. E. Hoyt. 2000. The Demand for Flood Insurance: Empirical Evidence. Journal of Risk and Uncertainty 20 (3): 29106.

Cochrane, H. C. 1992. Overview of Economic Research on Earthquake Consequences. In The Economic Consequences of a Catastrophic Earthquake: Proceedings of a Forum, edited by N. R. C. Committee on Earthquake Engineering, 101-11. Washington, DC: The National Academies Press.

Corey, C. M., and E. A. Deitch. 2011. Factors Affecting Business Recovery Immediately after Hurricane Katrina. Journal of Contingencies and Crisis Management 19 (3): 169-81.

Cruz, A. M., and L. J. Steinberg. 2005. Industry Preparedness for Earthquakes and Earthquake-Triggered Hazmat Accidents in the 1999 Kocaeli Earthquake. Earthquake Spectra 21 (2): 285-03.

Cutter, S. L., and C. Emrich. 2005. Are Natural Hazards and Disaster Losses in the US Increasing? EOS Transactions 86 (41): 381-88.

Dahlhamer, J. M., and L. Reshaur. 1996. Businesses and the 1994 Northridge Earthquake: An Analysis of Pre- and Post-Disaster Preparedness. Paper presented at the Annual Meeting of the Eastern Sociological Society, Boston, MA.

Dahlhamer, J. M., and M. J. J. D’Souza. 1997. Determinants of Business-Disaster Preparedness in Two U.S. Metropolitan Areas. International Journal of Mass Emergencies and Disasters 15 (2): 265-81.

Dillman, D. A. 1978. Mail and Telephone Surveys: The Total Design Method. New York: John Wiley \& Sons.

Dooley, D., R. Catalano, S. Mishra, and S. Serxner. 1992. Earthquake Preparedness: Predictors in a Community Survey. Journal of Applied Social Psychology 22 (6): 451-70.

Drabek, T. E. 1991. Anticipating Organizational Evacuations: Disaster Planning by Managers of Tourist-Oriented Private Firms. International Journal of Mass Emergencies and Disasters 9 (2): 219-45.

Drabek, T. E. 1994a. Disaster Evacuation and the Tourist Industry. Boulder, CO: Institute of Behavioral Science, University of Colorado.

Drabek, T. E. 1994b. New Study Shows that Growing Tourist Industry is Inadequately Prepared for Emergencies. Hazard Technology 14 (1): $17-21$.

Drabek, T. E. 1995. Disaster Responses within the Tourist Industry. International Journal of Mass Emergencies and Disasters 13 (1): $7-23$.

Finucane, M. L., P. Slovic, C. K. Mertz, J. Flynn, and T. A. Satterfield. 2000. Gender, Race, and Perceived Risk: The "White Male" Effect. Health, Risk \& Society 2 (2): 159-72.

Gujarati, D. 2011. Econometrics by Example. Hampshire, UK: Palgrave Macmillan.

Jackson, E. L. 1981. Response to Earthquake Hazard. Environment and Behavior 13 (4): 387-16.

Kunreuther, H. 1996. Mitigating Disaster Losses through Insurance. Journal of Risk and Uncertainty 12 (2): 171-87.

Kunreuther, H., R. Ginsberg, L. Miller, P. Sagi, P. Slovic, B. Borkan, and N. Katz. 1978. Disaster Insurance Protection: Public Policy Lessons. New York: Wiley.

Lindell, M. K., and R. W. Perry. 2000. Household Adjustment to Earthquake Hazard: A Review or Research. Environment and Behavior 32 (4): 461-501.
Lindell, M. K., and C. S. Prater. 2000. Household Adoption of Seismic Hazard Adjustments: A Comparison of Residents in Two States. International Journal of Mass Emergencies and Disasters 18 (2): 317-38.

MacCrimmon, K. R., D. Wehrung, and W. T. Stanbury. 1988. Taking Risks: The Management of Uncertainty. New York: Free Press.

Miceli, R., I. Sotgiu, and M. Settanni. 2008. Disaster Preparedness and Perception of Flood Risk: A Study in an Alpine Valley in Italy. Journal of Environmental Psychology 28 (2): 164-73.

Mileti, D. S., L. A. D. Darlington, C. Fitzpatrick, and P. W. O’Brien. 1993. Communicating Earthquake Risk: Societal Response to Revised Probabilities in the Bay Area. Boulder, CO: University of Colorado Natural Hazards Research and Application Information Center.

Mileti, D. S., T. E. Drabek, and J. E. Haas. 1975. Human Systems in Extreme Environments: A Sociological Perspective. Boulder: Institute of Behavioral Science, University of Colorado.

Mulilis, J. P., and R. Lippa. 1990. Behavioral Change in Earthquake Preparedness Due to Negative Threat Appeals: A Test of Protection Motivation Theory. Journal of Applied Social Psychology 20 (8): 619-38.

Nigg, J. M. 1995. Business Disruption Due to Earthquake-Induced Lifeline Interruption. Paper presented at the Sino-US Workshop on Post-Earthquake Rehabilitation and Reconstruction, Kunming, China.

Ozdemir, O., and C. Yilmaz. 2011. Factors Affecting Risk Mitigation Revisited: The Case of Earthquake in Turkey. Journal of Risk Research 14 (1): 17-46.

Peacock, W. G. 2003. Hurricane Mitigation Status and Factors Influencing Mitigation Status Among Florida's Single-Family Homeowners. Natural Hazards Review 4 (3): 149-58.

Pennings, J. M. E., and D. B. Grossman. 2008. Responding to Crises and Disasters: The Role of Risk Attitudes and Risk Perceptions. Disasters 32 (3): 434-48

Pratt, J. W. 1964. Risk Aversion in the Small and in the Large. Econometrica: Journal of the Econometric Society 32 (1-2): 122-36.

Quarantelli, E. L., C. Lawrence, K. Tierney, and T. Johnson. 1979. Initial Findings from a Study of Socio-Behavioral Preparations and Planning for Acute Chemical Hazard Disasters. Journal of Hazardous Materials 3 (1): 77-90.

Sadiq, A. A. 2010. Digging through Disaster Rubble in Search of the Determinants of Organizational Mitigation and Preparedness. Risk, Hazards \& Crisis in Public Policy 1 (2): Article No. 2.

Sadiq, A. A. 2011. Adoption of Hazard Adjustments by Large and Small Organizations: Who is Doing the Talking and Who is Doing the Walking? Risk, Hazards \& Crisis in Public Policy 2 (3): Article No. 6.

Siegrist, M., and H. Gutscher. 2008. Natural Hazards and Motivation for Mitigation Behavior: People Cannot Predict the Affect Evoked by a Severe Flood. Risk Analysis 28 (3): 771-78.

Slovic, P. 1987. Perception of Risk. Science 236 (4799): 280-85.

Slovic, P., M. L. Finucane, E. Peters, and D. G. MacGregor. 2004. Risk as Analysis and Risk as Feelings: Some Thoughts about Affect, Reason, Risk, and Rationality. Risk Analysis 24 (2): 311-22.

Tierney, K. J. 2001. Facing the Unexpected: Disaster Preparedness and Response in the United States. Washington, DC: National Academy Press.

Tierney, K. J. 2007. Businesses and Disasters: Vulnerability, Impacts, and Recovery. In Handbooks of Disaster Research, edited by H. Rodríguez, E. L. Quarantelli, and R. R. Dynes, 275-96. New York: Springer.

Tierney, K. J., and J. M. Nigg. 1995. Business Vulnerability to DisasterRelated Lifeline Disruption. In Proceedings of Fourth US Conference on Lifeline Earthquake Engineering, 72-79. American Society 
of Civil Engineers, Technical Council on Lifeline Earthquake Engineering. New York. Monograph Number 6.

UNISDR (United Nations International Strategy for Disaster Reduction). 2011. Economic Disaster Losses Increasing, Threatening All Regions, Rich and Poor Countries, Warns New United Nations Report. http://www.unisdr.org/archive/19849.

Wasileski, G., H. Rodriguez, and W. Diaz. 2011. Business Closure and Relocation: A Comparative Analysis of the Loma Prieta Earthquake and Hurricane Andrew. Disasters 35 (1): 102-29.
Webb, G. R., K. J. Tierney, and J. M. Dahlhamer. 2000. Businesses and Disasters: Empirical Patterns and Unanswered Questions. Natural Hazards Review 1 (2): 83-90.

Webb, G. R., K. J. Tierney, and J. M. Dahlhamer. 2002. Predicting LongTerm Business Recovery from Disaster: A Comparison of the Loma Prieta Earthquake and Hurricane Andrew. Global Environmental Change Part B: Environmental Hazards 4 (2-3): 45-58.

Weinstein, N. D. 1989. Effects of Personal Experience on SelfProtective Behavior. Psychological Bulletin 105 (1): 31-50.

Open Access This article is distributed under the terms of the Creative Commons Attribution License which permits any use, distribution, and reproduction in any medium, provided the original author(s) and source are credited. 